\title{
Larval condition and growth of Sardinella brasiliensis (Steindachner, 1879): preliminary results from laboratory studies ${ }^{\dagger *}$
}

\author{
CARMEN LÚCIA DEL BIANCO ROSSI-WONGTSCHOWSKI ${ }^{1}$, CATRIONA \\ CLEMMESEN $^{2}$, BERND UEBERSCHÄR ${ }^{2}$ and JUNE FERRAZ DIAS ${ }^{1 \ddagger}$ \\ ${ }^{1}$ Instituto Oceanográfico da Universidade de São Paulo, Praça do Oceanográfico, 191, Butantan, São Paulo, \\ SP 05508-900 Brazil. \\ ${ }^{2}$ Institut für Meereskunde an der Universität Kiel, Düsternbrooker Weg, 20, Kiel D-24105, Germany.
}

\begin{abstract}
SUMMARY: Brazilian sardine, the most important resource along the southeastern Brazilian coast, presented great variations and declines in its stocks. The main factors contributing to this are: oceanographic structure changes; recruitment failures; excessive catches of juveniles and increase in fishery effort. In spite of this, no alterations in the density-dependent parameters were detected. Consequently, methods analysing the condition of the larvae coupled with methods determining growth using sagittae otolith increment width were applied to evaluate growth under experimental conditions. The results of the readings on the sagittae were compared with the age of the laboratory-reared sardine larvae and confirmed that increments are formed on a daily basis. Under poor feeding conditions, sardine larvae showed a low growth expressed by dry weight, RNA/DNA ratio and tryptic enzyme activity and by the narrow and low contrast increments in the otoliths. The results of the biochemical indices showed an unexpected decline in the feeding group coupled with a decrease in width of increment numbers 8 and 10. Other factors than food availability were affecting the condition of the larvae and might be indicative of physiological processes and ontogenetic changes occurring in sardine larvae.
\end{abstract}

Key words: Brazilian sardine larvae, larval condition and growth, RNA/DNA ratio, tryptic enzyme activity, otolith microstructure.

RESUMEN: CONDICIÓN LARVARIA Y CRECIMIENTO DE SARDINELLA BRASILIENSIS (STEINDACHNER, 1879): RESULTADOS PRELIMINARES A PARTIR DE ESTUDIOS DE LABORATORIO. - La sardinela brasileña, el recurso más importante en la costa sudeste del Brasil, presentó grandes variaciones y disminuciones en sus poblaciones. Los principales factores que contribuyeron a dicha situación fueron: los cambios en la estructura oceanográfica, los fallos en el reclutamiento, las capturas excesivas de juveniles y el aumento del esfuerzo pesquero. A pesar de ello, no se detectaron alteraciones en los parámetros denso-dependientes de la población. Consecuentemente, se aplicaron métodos de análisis de condición larvaria junto a métodos de determinación del crecimiento mediante la anchura de los incrementos de los otolitos sagitta para evaluar el crecimiento bajo condiciones experimentales. Los resultados de las lecturas de los sagitta se compararon con la edad de las larvas de sardinela cultivadas en el laboratorio y confirmaron que los incrementos se forman diariamente. Las larvas de sardinela sometidas a bajos niveles de alimentación mostraron un bajo crecimiento expresado en peso seco, relación RNA/DNA y actividad de la tripsina, y un bajo contraste de los incrementos en los otolitos. Los resultados de los índices bioquímicos mostraron un inesperado descenso en el grupo de larvas alimentadas, acompañado de una disminución en la anchura de los incrementos 8 y 10. Además de la disponibilidad de alimento, otros factores afectaron a la condición de las larvas y podrían indicar procesos fisiológicos o cambios ontogenéticos que tienen lugar en el desarrollo larvario de la sardinela.

Palabras clave: sardinela brasileña, larvas, condición, crecimiento, cociente RNA/DNA, actividad tripsina, microestructura otolitos.

Project MAR 27 - Brazilian-German Science and Technology

Cooperation in Marine Sciences (MCT-CNPq/WTZ).

*Received October 20, 1999. Accepted July 24, 2002.

¥Corresponding author. 


\section{INTRODUCTION}

The Brazilian sardine is the commercially most important fish on the south-eastern Brazilian coast and supports the most important fishery, with total annual catches around 150,000 t. Large fluctuations and a decline in its population and stock size have been occurring in the last 20 years (Valentini and Cardoso, 1991; Matsuura, 1996; Rossi-Wongtschowski et al., 1996; Cergole et al., in press.).

Since 1985, several programmes have dealt with recruitment variability of the Brazilian sardine using age estimations of larvae and juveniles through otolith microstructure and ichthyoplankton surveys (Yoneda, 1987; Matsuura, 1989, 1996). More recently, the estimation of larval condition through biochemical and morphometric indicators has been included (Dias, 1995).

Previous data demonstrate that the Sardinella brasiliensis (Steindachner, 1879) stock is decreasing and the causes of this have been attributed to recruitment failures as a result of the impact of high fishing pressure on the adult stock, and to variability in the local oceanographic conditions during the spawning season (Valentini and Cardoso, 1991; Matsuura, 1996; Rossi-Wongtschowski et al., 1996). In spite of the decrease in the sardine stock, no alterations in the batch fecundity, the gonado-somatic ratio, the condition factor, the length at first maturation and the growth rate have been detected (RossiWongtschowski et al., 1996).

Although information is available from intensive studies both on early life history and on the adult phase, so far only limited information is available on survival potential in the field. Dias (1995) analysed the feeding and nutritional condition of field-caught sardine and anchovy larvae from Brazilian waters, measuring the tryptic enzyme activity, RNA/DNA ratio, protein content and allometric condition factor, but since calibration values for the biochemical indicators were not available for these species, her results were discussed in relative terms and compared to herring calibration experiments performed by Clemmesen (1994) and Ueberschär (1988). Brazilian sardine larvae were found to be in bad condition at $50-70 \%$ of the stations sampled, and between 7 and $36 \%$ of the larvae were in starving condition considering all samples in the area investigated (Dias, op. cit.). Intrusions of the South Atlantic Central Water can promote an up to 10 fold increase in the primary production of the coastal water (Aidar et al., 1993) and these events were related to the better condition of the larvae in the areas of intrusion.

Quantitative evaluation of the growth rate and condition of larvae in relation to environmental factors is an essential pre-requisite to the predictive assessment of survival potential. In particular, to understand recruitment variability, the identification of the nutritional condition of larvae in the field populations is a powerful tool for evaluating survival probability.

In the last two decades studies on nutritional condition of fish larvae from laboratory or field studies based on changes in molecular (biochemical), cellular/tissues characteristics and otolith microstructure were applied. All of the indicators used give different temporal responses reflecting the physiological processes assessed (Suthers, 1998).

The biochemical indicator tryptic enzyme activity was found to be an appropriate indicator for growth and survival potential (Hjelmeland et al., 1984) and well suited to monitor nutritional condition in relation to feeding activity. Tryptic-like enzymes are present in a measurable amount even in the youngest stages of fish larvae and their potential food organisms. The indicator trypsin was investigated in relation to feeding regimes and demonstrated its usefulness when questions concerning digestive processes and nutritional condition in fish larvae were regarded (e.g. Lauff and Hofer, 1984; Pedersen et al., 1987; Ueberschär, 1988; Pedersen et al., 1990; Ueberschär and Clemmesen, 1992, Ueberschär, 1999, MacKenzie et al., 1999).

The relationship between RNA and DNA is an index of the cell's metabolic intensity and has been used to measure recent growth in fish (Bulow, 1987; Buckley and Lough, 1987; Hovenkamp, 1990; Hovenkamp and Witte, 1991) and the nutritional condition in larval fish studies (Buckley, 1980, 1984; Martin et al., 1985; Fukuda et al., 1986; Buckley and Lough, 1987; Raae et al., 1988; Robinson and Ware, 1988; Clemmesen, 1994; Chícharo, 1997, 1998; Kimura et al., 2000).

Biochemical indicators have also been used to demonstrate starvation mortality in the field and correlations between food availability or environmental characteristics and condition of the larvae (SetzlerHamilton et al., 1987; Canino et al., 1991; Clemmesen et al., 1997; Chícharo et al., 1998; Ramírez et al., 2001). A positive relationship of RNA/DNA ratio and prey abundance has been shown for stripped bass larvae (Martin et al., 1985), Atlantic cod and haddock larvae (Buckley and Lough, 1987) and Baltic cod (Grønkjær et al., 1997). 
Microstructural growth patterns in otoliths of teleost fish and age validation studies of larval and juvenile otoliths have shown that microstructural characteristics are species-specific and may be influenced by nutrition and environmental variables (Campana and Neilson, 1985; Jones, 1986; Maillet and Checkley, 1989; Bradford and Geen, 1992). Recent reports on the relationship between daily somatic growth and incremental growth of otoliths support the use of increment widths as a measure of daily somatic growth (Secor and Dean, 1989; Hovenkamp, 1989, 1990; Moksness and Fossum, 1991). These microstructural studies of fish otoliths may provide a record of environmental and physiological condition through the larval and juvenile stages and hence important information about processes regulating recruitment in fish (Pannella, 1980; Rice et al., 1987; Moksness, 1992; Fossum and Moksness, 1993).

The combination of biochemical methods, otolith growth and microstructure studies have been used as an indicator of the larval growth history as well as the condition at catch (Hovenkamp, 1990; Hovenkamp and Witte, 1991; Suthers et al., 1992; Clemmesen, 1994; Clemmesen and Doan, 1996).

The aim of this study was to assess the effect of feeding and food withdrawal on the condition of the Brazilian sardine (Sardinella brasiliensis) larvae measured by morphometric and biochemical indices coupled with otolith microstructure analysis. Laboratory rearing experiments were performed on sardine larvae aged from 1-13 days after hatching to relate the RNA/DNA ratios and tryptic enzyme activity values to otolith increment widths under feeding and starving conditions and to create laboratory calibration values to evaluate the condition of field caught sardine larvae based on the critical values below which they can be classified as starved.

\section{MATERIAL AND METHODS}

Brazilian sardine eggs were caught on November $4^{\text {th }}$ and $14^{\text {th }}, 1995$, in waters over the Brazilian continental shelf in the northern area of the São Paulo state, with a Hensen net (diameter $80 \mathrm{~cm}$, length 2 $\mathrm{m}$, mesh size $333 \mu \mathrm{m}$ ) towed horizontally for 5-10 min. in surface waters and in ca. 3 m depths. Mean water temperature was $24.3^{\circ} \mathrm{C}$ in the field. Samples taken were immediately checked for eggs on board under a binocular. The samples were transported in less than 1 hour under constant aeration to the coastal station of the Oceanographic Institute - University of São Paulo in Ubatuba. Sardine eggs in initial stages of development were separated from the rest of the plankton by pipetting them out of Petri dishes and checking the species under the binocular. Hatching occurred on the day of capture, only a few hours later.

Circular tanks made of watersealed canvas with a diameter of $115 \mathrm{~cm}$ were available for the rearing of the larvae. 601 and 201 capacity glass aquaria were also provided. To perform starvation experiments four 101 incubation containers with a $50 \mu \mathrm{m}$ mesh at the bottom were prepared. The temperature in the rearing tanks ranged from 21.3 to $25.1^{\circ} \mathrm{C}$, reflecting field conditions.

The algae Tetraselmis tetrathelle were kept in a temperature controlled room $\left(25-28^{\circ} \mathrm{C}\right)$ at constant illumination as stock cultures, cultured in Conway medium as a basis for mass culture as food for the rotifers which were applied as first food for the sardine larvae. Replicate cultures were started every 23 days and used for the outside bag cultures. Algae were grown in plastic bags ( 251 volume) in seawater (33 PSU) filtered with $2 \mu \mathrm{m}$ pore size filters. The plastic bags were put up outside under a rainproof veranda tied to the roof and were illuminated by natural light from 6:00 to 20:00 h and artificial light from 20:00 until 6:00 h. Temperature was measured daily three times a day. The outside cultures were grown on a commercial nutrient solution containing nitrogen, phosphate and potassium.

Rotifers Brachionus plicatilis (amictic females, strain "small" and "large") were cultured in the plastic bags under the same conditions as described for the outside algae culture and fed on algae solutions and enriched with fatty acid solution (Superselco). Additionally rotifers were kept inside in the laboratory in circular containers fed once a day on baker's yeast at a concentration of $1 \mathrm{~g}$ yeast/ 1 million rotifers as a backup for the outside cultures. Reproduction rates of the rotifers were determined by microscopic counting of the densities.

During the course of the experiments the outside algae and rotifer cultures were grown at temperatures ranging from 20.4 to $32.1^{\circ} \mathrm{C}$ with the peak occurring in the afternoons. As the outside temperature increased, bacteria and ciliates gained noticeable densities. Therefore, sometimes rotifer cultures had to be treated with commercial chemicals to stop ciliate contamination before being fed to the fish larvae.

After the absorption of the yolk sac, larvae from samples taken on $4^{\text {th }}$ and $14^{\text {th }}$ November were trans- 
ferred to different aquaria and starvation experiments were carried out with 2 to 8 and 2 to 13 dayold larvae deprived of food for 1 to 2 days. In the control experiments, larvae were fed with $\mathrm{Bra}$ chionus reared on the Tetraselmis "ad libidum", twice a day, at 12:00 and 18:00 h.

Larvae from the experimental rearing were taken for biochemical measurements (RNA/DNA ratios and tryptic enzyme activity) and for otolith analysis, preserved in liquid nitrogen and stored in a deep freezer $\left(-70^{\circ} \mathrm{C}\right)$. The larvae were sampled for each kind of analysis every day at the same hour (10:00 h) to avoid the inclusion of diel variation in the rhythm of the RNA synthesis reported for other fish larvae of the same family (Chícharo et al., 1998). The biochemical measurements were not performed on the same individual larvae but on larvae from the same aquaria. Due to high mortality rates, the experiment was terminated by day 13 after hatching.

RNA/DNA ratios and tryptic enzyme activity were determined according to the analytical technique described by Clemmesen (1993) and Ueberschär (1995), on entire individual fish larvae, after measurement of total length and checking for possible damage. Damaged larvae were excluded from all analyses. Prior to determination of RNA and DNA, individual dry weights for the fish larvae were taken after freeze drying for $24 \mathrm{~h}$. Nucleic acids were extracted and purified from larval homogenates and their total content was fluorimetrically determined using ethidium bromide as a dye. In order to measure the DNA content of the larvae, RNA was enzymatically digested by RNase and the remaining DNA was determined with ethidium bromide. Detailed instructions and reagents can be found in Moksness et al. (2000). Tryptic enzyme activity was measured in individually homogenized sardine larvae using N $\alpha$-benzoyl-L-arginin-methylcoumarinylamide (MCA) as the substrate and the relative fluorescence was recorded every $2 \mathrm{~min}$. over $10 \mathrm{~min}$. The resulting tryptic enzyme activity is given as the amount of hydrolysed substrate per time unit $\left(\mathrm{nmol} \mathrm{min} \mathrm{m}^{-1}\right.$ ) per larva.

For the otolith analyses, larvae were rinsed in distilled water and the total length was measured. Sagittae were identified and dissected using fine insect needles under a binocular microscope. These otoliths were mounted on glass slides using permount glue. It was not necessary to polish the otoliths due to the delicate texture and the young age of the larvae. The measurements of the sagittae were performed using a digitalised computer-aided video system, with a
TABLE 1. - Numbers of fed and unfed Brazilian sardine larvae reared at $24.3^{\circ} \mathrm{C}$ and analyzed by different methods. Asterisks mean that the same larva was measured by the same indicators.

\begin{tabular}{lcc}
\hline indicator & $\begin{array}{c}\text { number of } \\
\text { fed larvae }\end{array}$ & $\begin{array}{c}\text { number of } \\
\text { 1-2 days unfed larvae }\end{array}$ \\
\hline dryweight & $93 *$ & $23^{*}$ \\
tryptic enzyme activity & 94 & 49 \\
RNA & $130 *$ & $45^{*}$ \\
DNA & $130^{*}$ & $45^{*}$ \\
otoliths & 63 & 48 \\
\hline
\end{tabular}

CCD camera connected to a microscope at $1000 \mathrm{X}$ magnification. Since the otoliths are round, radii, the number of increments and widths of the otoliths were measured 3-4 times in 3 different positions (directions) and the means were calculated.

\section{RESULTS}

The results of experiments performed with eggs from two sources ( $4^{\text {th }}$ and $14^{\text {th }}$ November), from day 1 to day 8 and from day 1 to day 13 after hatching,
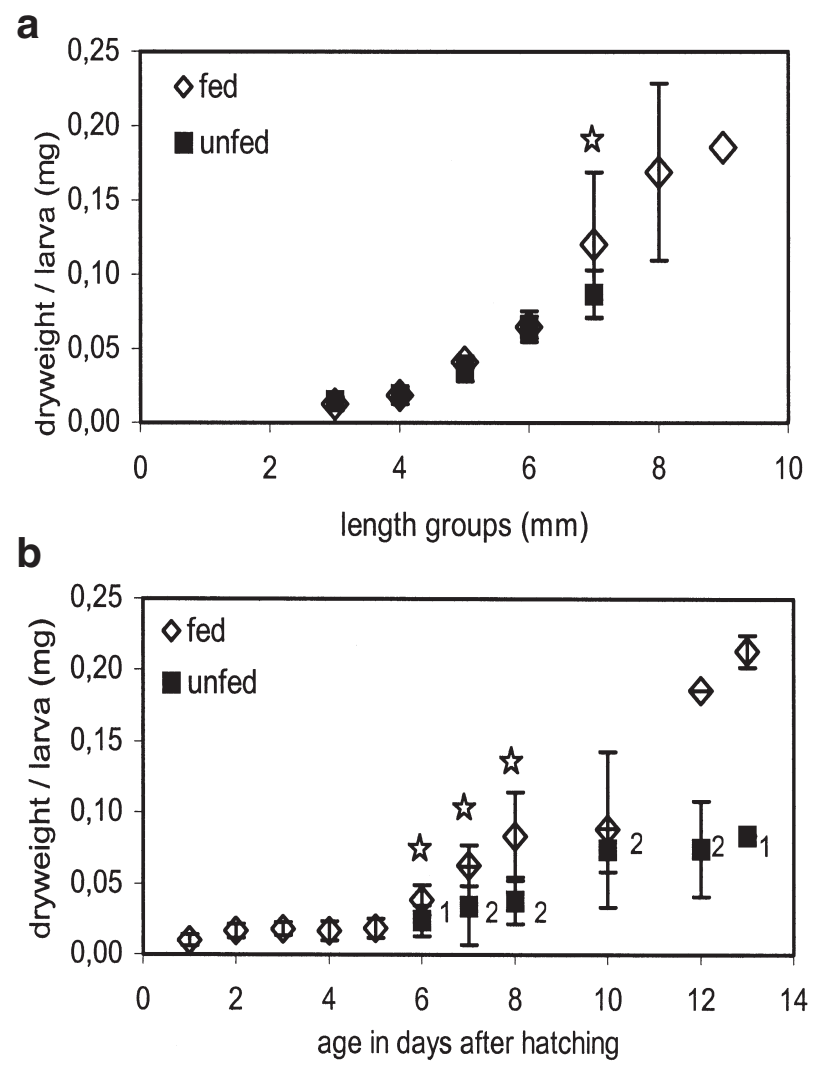

FIG. 1. - Relationship between length group (a), age (b) and mean dry weight per larva of fed and unfed (1-2 days) Brazilian sardine larvae. Vertical bars indicate standard deviations of the means. Stars mean significant differences between unfed and fed sardine larvae of the same length groups or age (Mann-Whitney U-test, $\mathrm{p}<0.05)$. 

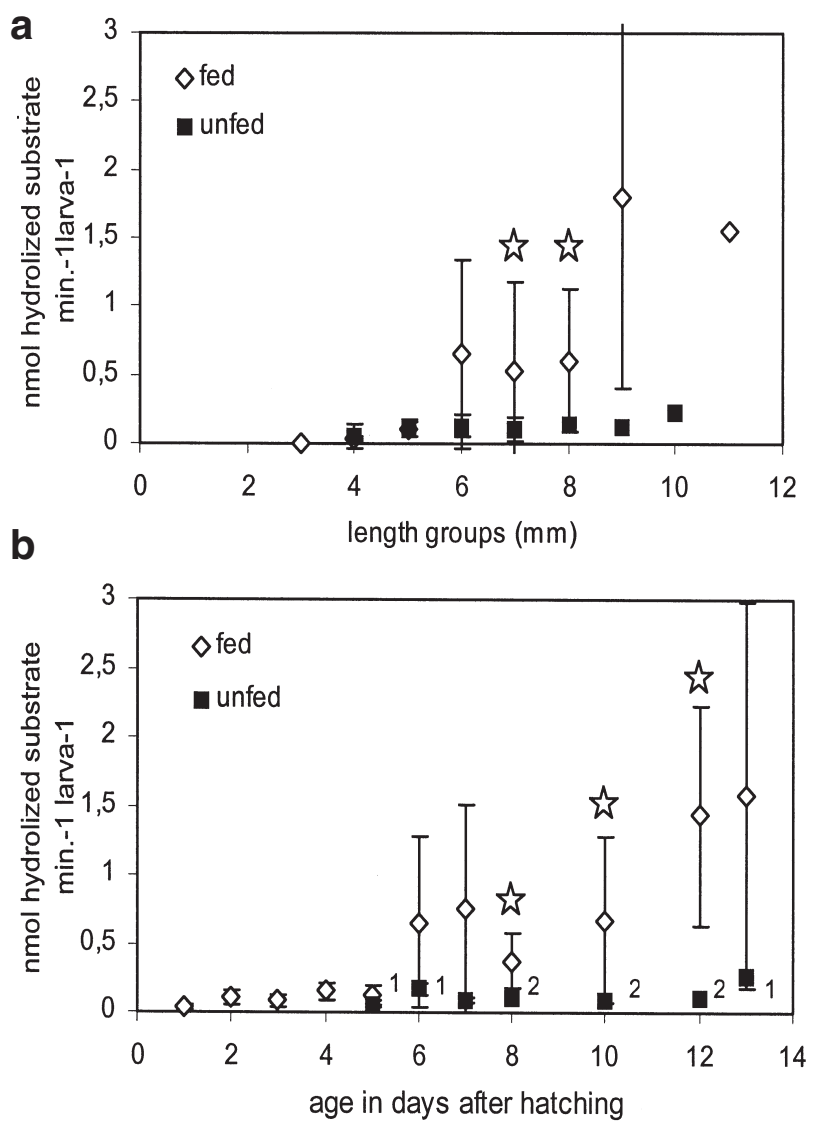

FIG. 2. - Relationship between length group (a) and age (b) and mean tryptic enzyme activity of fed and unfed Brazilian sardine larvae. In (b) numbers indicate the days deprived of food. Vertical bars indicate standard deviations of the means. Stars mean significant differences between unfed and fed sardine larvae at same length groups or age (Mann-Whitney U-test, $\mathrm{p}<0.05$ ).

were pooled, according to the age or the length group of the larvae. The nonparametric Mann-Whitney U-test $(\mathrm{p}<0.05)$ procedure was applied for testing differences between fed and unfed larvae. Table 1 gives the number of larvae used for the different procedures.

Sardine larvae showed mean dry weights ranging from $10 \mu \mathrm{g}$ to $225 \mu \mathrm{g}$ ( $\mathrm{n}=93$ larvae). The lengthweight relationship was $\mathrm{Y}=0.0005 \mathrm{X}^{2.67}\left(\mathrm{r}^{2}=0.98\right)$ for fed larvae and $Y=0.0011 \mathrm{X}^{2.22}\left(\mathrm{r}^{2}=0.95\right)$ for unfed sardine larvae. The dry weight-length relationship showed reduced weight at a given length in the group deprived of food (Fig. 1a). Larvae deprived of food for 1-2 days showed a lower dry weight in comparison to the same age group having received food during the whole course of the experiment (Fig. 1b).

The reaction of the tryptic enzyme activity related to larval length in the feeding and starving groups showed an increase in mean values in the fed group
(Fig. 2a). Tryptic enzyme activity measurements applied to laboratory reared fed and unfed larvae 1 to 13 days after hatching showed that from day 1 to day 5 , only a slow increase in the activity with age could be seen, but in fed larvae from day 6 to 13 a more pronounced increase in tryptic activity was observed, with a decrease from day 7 to 8 (Fig. 2b). The larvae deprived of food for 1 to 2 days showed a decrease in enzyme activity which was more pronounced in older larvae. A regression line fitted to the data length groups and tryptic enzyme activity of unfed larvae is described by the equation: $\mathrm{Y}=-0.0158+0.0206 \mathrm{X}\left(\mathrm{r}^{2}=0.72\right)$, and represents the laboratory critical line for the pre-flexion and flexion Brazilian sardine larvae, below which larvae can be classified as starving. The value of $r^{2}$ indicates a significant regression between the two variables.

DNA-content in relation to larval length and age is given in Figure 3 ( $a$ and $b$ ) with the feeding group showing a greater increase in DNA-content than the

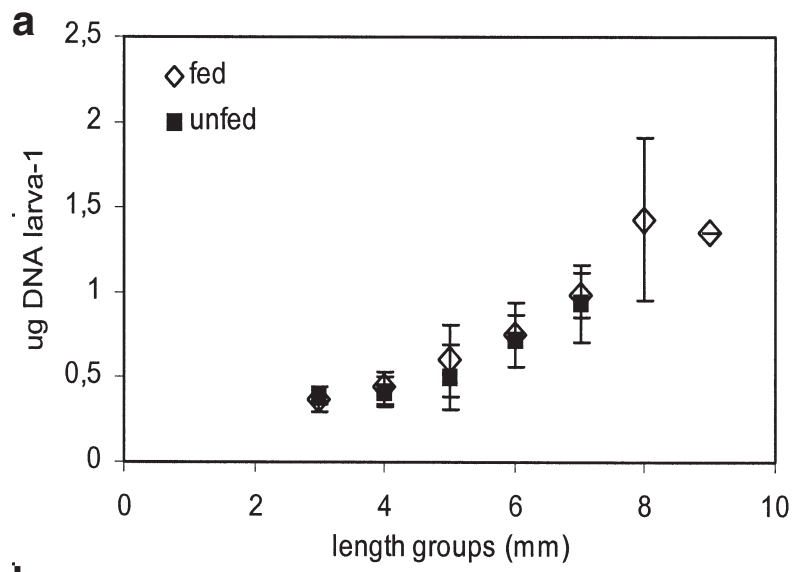

b

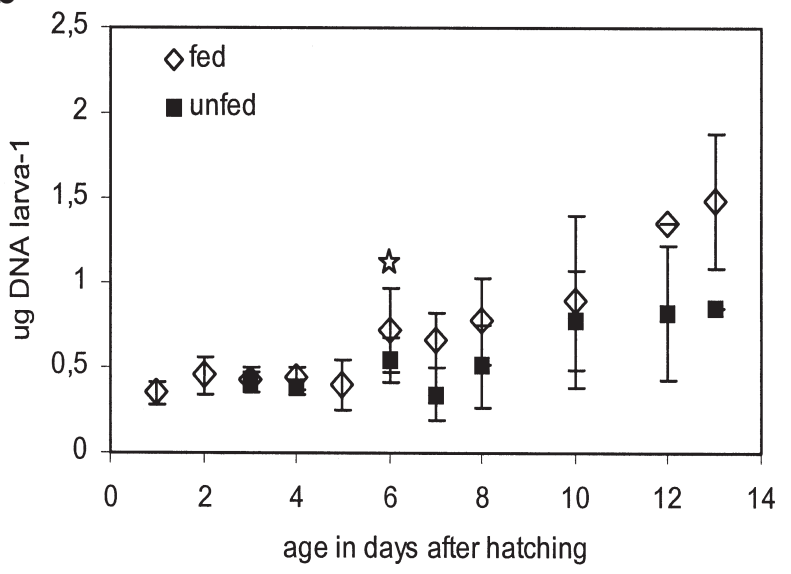

FIG. 3. - Mean values of DNA- content per larvae related to length (a) and age (b) of fed and unfed sardine larvae. Vertical bars indicate standard deviation of the means. There were no statistical significant differences between fed and unfed larvae in relation to length. Star means significant differences between unfed and fed sardine larvae at same age (Mann-Whitney U-test, $\mathrm{p}<0.05$ ). 

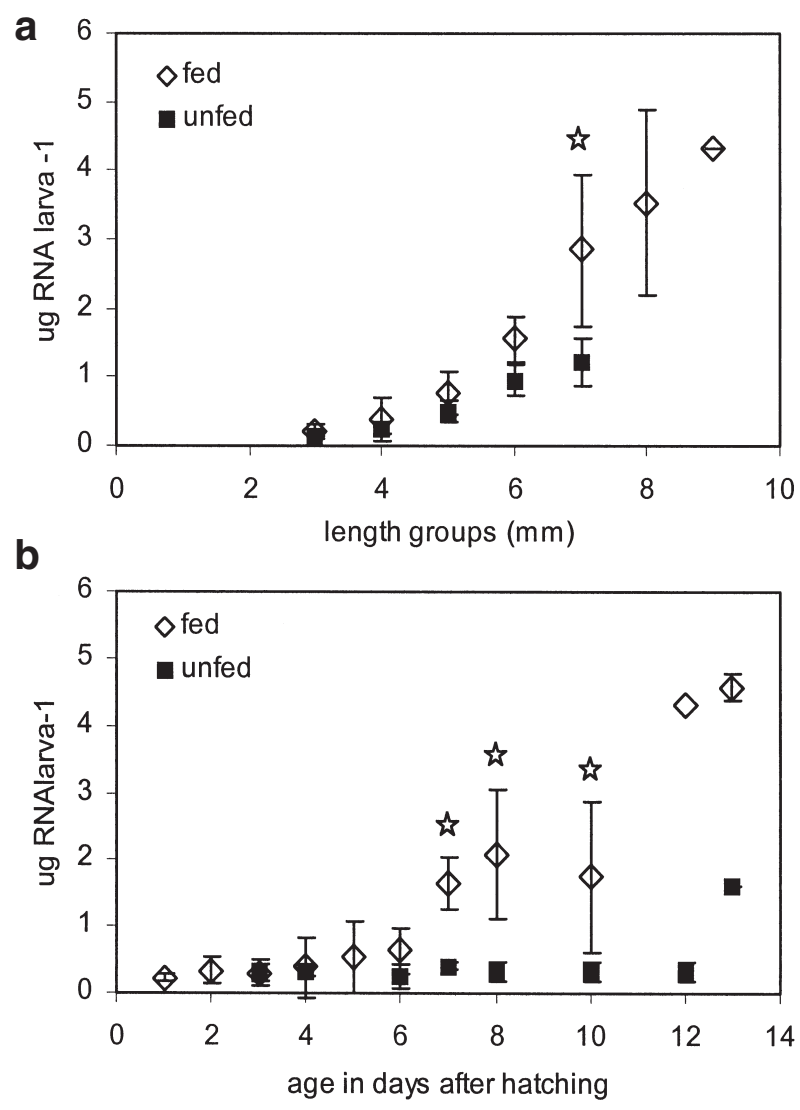

FIG. 4. - Mean values of RNA-content per larvae related to length (a) and age (b) of fed and unfed sardine larvae. Vertical bars indicate standard deviation of the means. Stars mean significant differences between unfed and fed sardine larvae of the same length groups or age (Mann-Whitney U-test, $\mathrm{p}<0.05$ ).

unfed larvae for 1 or 2 days. The RNA-content in relation to larval age and length (Fig. 4a and b) showed an increase in the feeding group, but there were indications of a decrease in RNA-content between day 8 and 10 (Fig. 4b). RNA-content of the starving groups was generally lower. RNA/DNA ratios in relation to larval length of fed and 1 to 2 days unfed sardine are presented in Figure 5a. The starved larvae showed lower levels of RNA/DNA ratios. The fitted regression model of the unfed individuals represents the critical values for unfed preflexion and flexion larvae and is described by the equation $\mathrm{Y}=-0.39+0.27 \mathrm{X}\left(\mathrm{r}^{2}=0.94\right)$. These values can be taken as a laboratory critical level line to evaluate small $(3-9 \mathrm{~mm})$ field sampled larvae. In relation to age, the RNA/DNA ratios of 1-2 days starving larvae always showed a decrease, whereas the ratios of fed larvae had the tendency to increase with larval age except for the reductions in the ratio found between day 5 and day 6 and day 8 and 10, reflecting the situation found in the RNA-content (Fig. 5b).
To determine the accuracy of the age estimation using the number of otolith increments, the results of the readings on the sagittae were compared with the known age of the laboratory-reared fed and unfed sardine larvae and confirmed that increments are formed on a daily basis ( $b=0.96$ for fed larvae; $b=0.81$ for unfed larvae), regardless of the feeding conditions (Fig. 6a and b).

The time to first increment formation was estimated from linear regressions of mean increment count on days after hatching for fed and unfed larvae:

$$
\begin{aligned}
& \text { Fed larvae: } \mathrm{Y}=0.96 \mathrm{X}-1.64\left(\mathrm{r}^{2}=0.98\right) \\
& \text { Unfed larvae: } \mathrm{Y}=0.81 \mathrm{X}-1.38\left(\mathrm{r}^{2}=0.95\right)
\end{aligned}
$$

The regression intercepts of larvae from the fed and the unfed group indicated that the first increment is formed around the second day after hatching and after start of feeding. The slopes (regression coefficients) of these two equations are not significantly different $(t$ test, $\mathrm{P}<0.05)$.
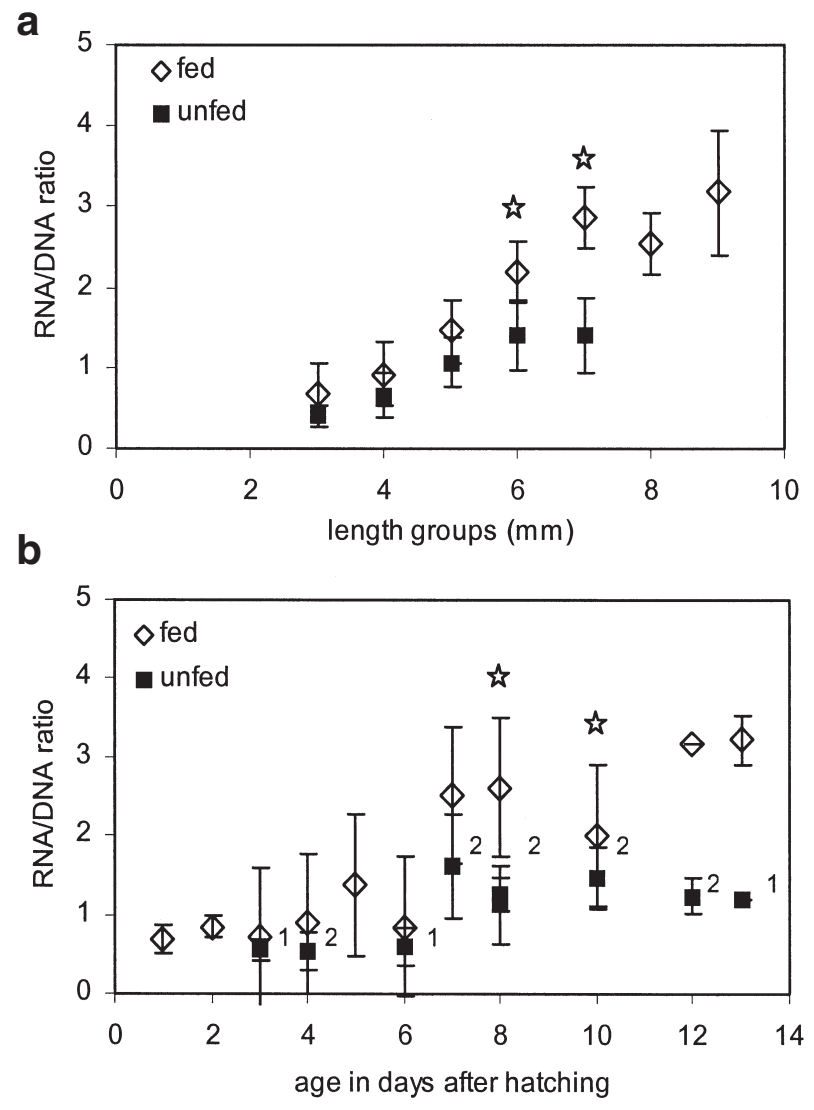

FIG. 5. - Mean RNA/DNA ratios in relation to larval length (a) and age (b) of fed and 1-2 days unfed Brazilian sardine larvae. In (b) numbers indicate the days deprived of food. Vertical bars indicate standard deviation of the means. Stars mean significant differences between unfed and fed sardine larvae of the same length groups or age (Mann-Whitney U-test, $\mathrm{p}<0.05$ ). 


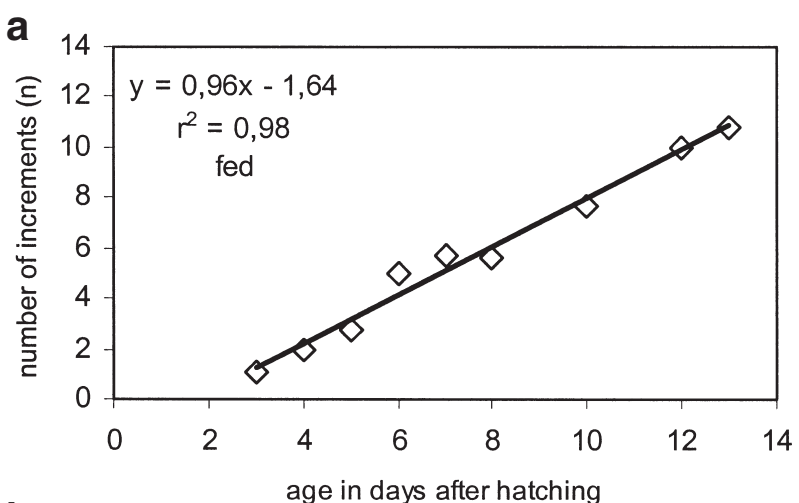

b

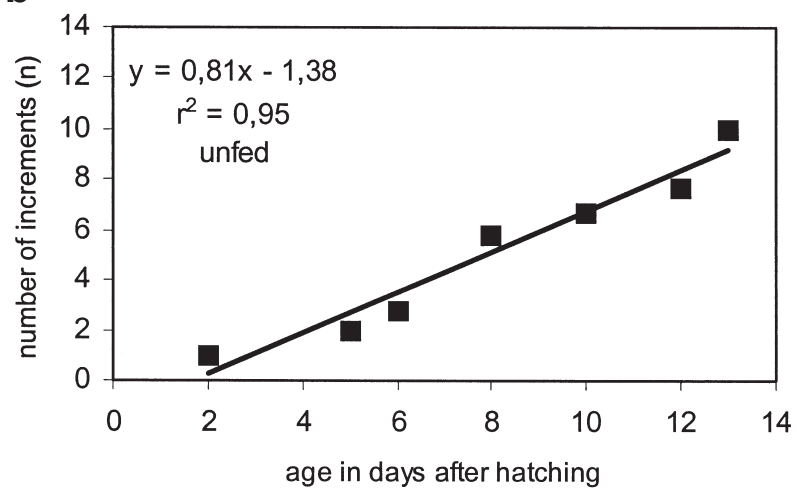

FIG. 6. - Comparison between known age and mean number of otolith rings (increments) of fed (a) and unfed (b) Brazilian sardine larvae. Line was fitted by linear regression.
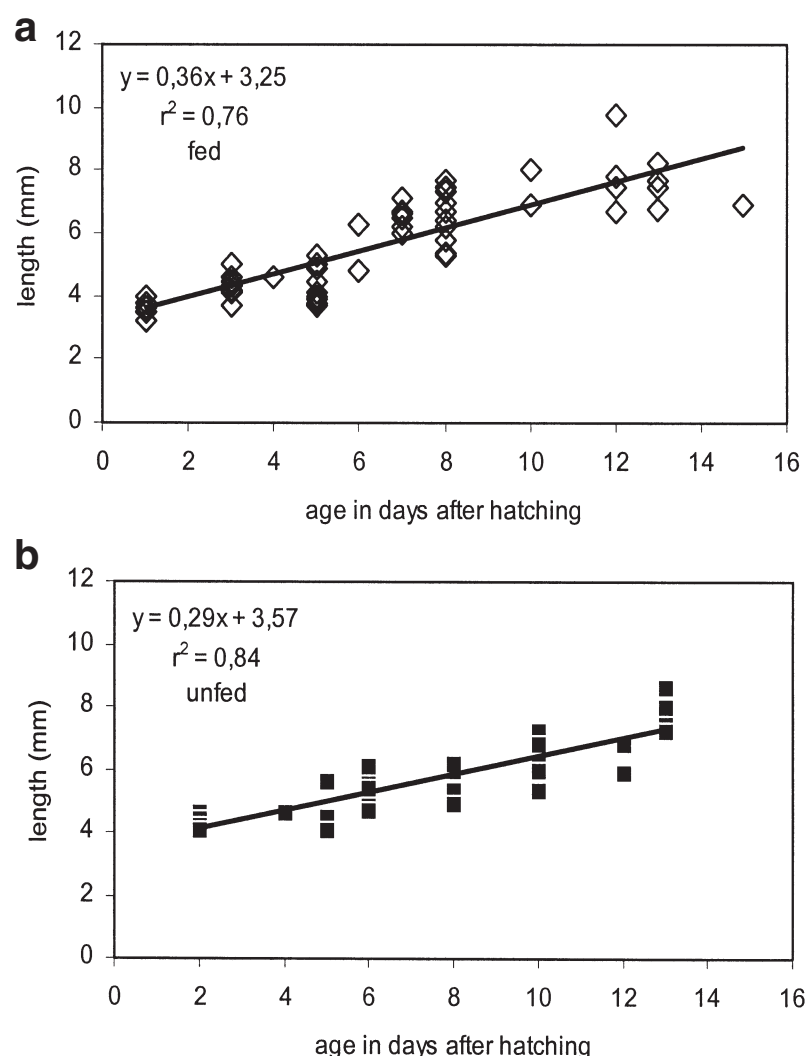

FIG. 7. - Relation between age and length of fed (a) and unfed (b) Brazilian sardine larvae. Line was fitted by linear regression.

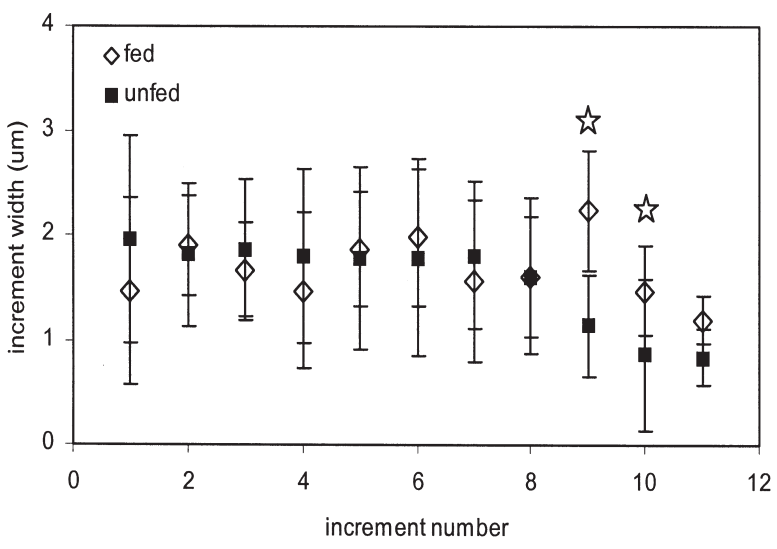

FIG. 8. - Relation between number of increments and mean increment width from the otoliths of fed and unfed Brazilian sardine larvae reared in the laboratory. Vertical bars indicate standard deviation of the means. Stars indicate significant differences (MannWhitney U-test, $\mathrm{p}<0.05$ ).

Based on linear regression models fitted to the data (Fig. 7a and b), the growth equations were calculated for fed and unfed Brazilian sardine larvae:

Fed larvae: $\mathrm{Y}=3.25+0.36 \mathrm{X}\left(\mathrm{r}^{2}=0.76\right)$

Unfed larvae: $\mathrm{Y}=3.57+0.29 \mathrm{X}\left(\mathrm{r}^{2}=0.84\right)$

The same increment number did not show significant differences in the increment width of the otolith in the first days for fed and unfed larvae (Fig. 8 ), but increment widths showed a decline between increment numbers 8 and 11 in unfed larvae. Although smaller in fed larvae, this decrease was noted from day 9 to 11 . Increment width showed significant differences in increment numbers 9 and 10 for fed and unfed larvae.

Figure 9 demonstrates the relationship between biochemical indicators and otolith microstructure in the feeding group. There is a decrease in RNA/DNA

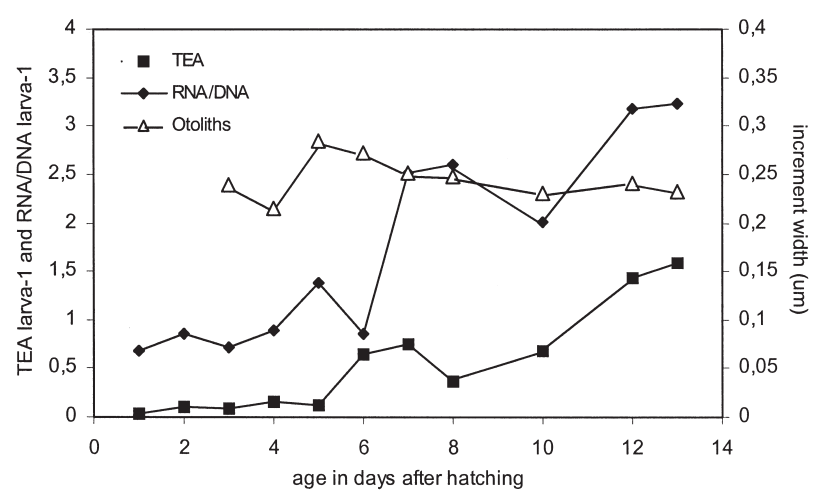

FIG. 9. - Comparison between the results of mean tryptic enzyme activity (TEA), mean RNA/DNA ratios and mean otolith increment widths of fed Brazilian sardine larvae showing a decrease in the values of all indicators. Errors bars have been omitted for clarity. 
ratios and increment width around day 6 of the experiment that is not shown by enzyme activity. In the experimental feeding group, a decrease in the mean values of tryptic enzyme activity (day 7 to 8), followed by a decrease in RNA/DNA ratio from day 8 to 10 and also a decrease in the increment width between day 8 and 10, was detected. This decrease in the increment width of the otoliths is coupled with a decrease in the biochemical parameters but occurred at the same day as RNA/DNA ratio but one day later than enzyme activity.

\section{DISCUSSION}

Starvation has been suggested to be one of the most important sources of mortality of fish larvae. To be able to apply morphometrical/biochemical indicators and otolith microstructure analysis for the evaluation of growth and survival potential in field settings, laboratory experiments had to be performed, since no calibration data for Brazilian sardine were available. Although laboratory experiments should be considered with caution because they do not simulate the ocean environment (Chícharo, 1997; Suthers, 1998), the trends observed under laboratory conditions can be an indicator of trends and patterns.

\section{Biochemical methods}

The tryptic enzyme activity analysis measures the amount of protein digestion from the food taken up, and consequently its variations can be rapidly detected in the range of hours (Ueberschär, 1995). Low RNA values and consequently RNA/DNA ratios observed in the starving larvae indicate that the precursors of protein synthesis are not being transcripted in high amounts. The measures of these biochemical indicators have different times of reaction and this could explain the delay detected (Ueberschär and Clemmesen, 1992).

The tryptic enzyme activity and the RNA/DNA ratio showed a decrease compared to fed larvae after 1-2 days of food withdrawal. In fish larvae of temperate waters a significant reaction of tryptic enzyme activity measures in response to food deprivation is in the range of 2-3 days (Ueberschär, 1999), whereas the RNA/DNA ratio needs 3-5 days of food deprivation to significantly decrease (Clemmesen, 1994; Ferron and Leggett, 1994). In this study the effect of higher temperature caused a faster reaction in the decrease of RNA/DNA values, reaching the same minimum values necessary for survival (Clemmesen, 1994) but in 1-2 days. Since higher temperature causes higher metabolic rates, starvation induced mortality in species living in high temperature regimes can very probably affect recruitment success, and mortality due to starvation could be very high as indicated by the fast reaction time of the biochemical indicators.

\section{Otolith microstructure analysis}

In order to achieve reliable growth rates based on otolith microstructure increments, the deposition has to be formed daily and increment width has to reflect somatic growth (Pannella, 1971). Age validation studies of larval and juvenile fishes have shown that otolith microstructure is influenced by nutrition and environmental variables and is species-specific, and that periods of stress (like food withdrawal) or cyclic environmental variables may result in apparent non-daily formation (Campana and Nielson, 1985; Neilson and Geen, 1985; Rice et al. 1985, 1987). Therefore, validation studies are necessary before analysis of otolith microstructure can be used in the field for Brazilian sardine.

The otoliths of fed and unfed sardine in this study showed the typical otolith pattern described by Yoneda (1987), with deposition of the first ring two days after hatching. The deposition of growth increments followed a daily pattern, strictly related to chronological age, independent of growth rate and feeding conditions. Age estimates are therefore calculated based on the number of increments found plus an extra two days.

A decrease in increment width between day 8 and 10 was coupled with a decrease in the biochemical parameters but occurred one to two days later than tryptic activity as an indicator of feeding activity and condition, suggesting differences in latency time, but coupled with RNA/DNA ratios. Campana (1984) observed a lag between feeding and otolith growth in starry flounder. Mosegaard et al. (1988) found a decoupling between somatic growth and otolith growth rates at hyperoptimal temperatures and suggested that metabolic activity, not necessarily somatic growth rate, governs otolith growth rate. Observations showing the relationship between growth rates over the last 5 days (as determined from the width of daily otolith increments) and protein growth rates based on nucleic acid determinations have been described by Hovenkamp (1990), Hovenkamp and Witte (1991) and Clemmesen and Doan (1996) and 
the results showed that the reaction of the otolith growth and somatic growth is coupled and allows one to determine whether the larval condition is improving or deteriorating. Mugiya and Oka (1991) compared variations in calcium deposition in otoliths and RNA/DNA ratios in muscle of adult rainbow trout (Oncorhynchus mykiss), and showed positive relationships through several days after starvation and during dial experiments. However, uncoupling was found in the recovery processes after refeeding conditions, and calcium deposition on the otoliths transiently recovered on day 1 after refeeding, while RNA/DNA ratios reached the levels of control groups after 4 days of refeeding.

Since the otolith is an acellular product secreted by otolith-forming cells, the explanation that the authors presented for otolith repletion was that starvation may interrupt the releasing activity partly due to the reduced processing of secretory product. This would inversely result in some accumulation of otolith precursor material in the cells. A steady-state recovery in synthesis and processing of the secretory product is probably also a time-consuming process, running parallel to the recovery of RNA/DNA ratios in muscle.

Investigations by Gauldie and Nelson (1988) have shown that neuroproteins secreted in the macula control the rate of aragonite crystal growth. Neuroprotein secretion is continuously modulated, so narrow mineral deficient bands and wider mineral dense bands alternate to constitute daily increments. This secretion is subjected to temperature effects and to supply of physiological calcium ions. Unfortunately there is no investigation about the time scale of this process.

The observed decrease in biochemical indicators and otolith microstructure in the feeding group indicated that other factors than food availability were affecting the condition and growth of the larvae, since food in sufficient amount was available. This is an important point for the Brazilian sardine: whether somatic growth and otolith growth reacts in the same time scale in this tropical fish species.

Our results showed that between ages 7 and 12 a variation in all 3 indicators (biochemical and otolith analysis) takes place, suggesting some energy consuming events involving structural and metabolic changes (Blaxter, 1988; Bergeron, 1997) occurring during organogenesis. At 7-10 mm Brazilian sardine larvae is in the phase of notochord flexion (Kurtz and Matsuura, 2001) and these lengths are in the range of the ages mentioned above. This is a very important event in the life history, increasing the swimming capacity and the probability of capturing food (Blaxter, 1988; Ramírez et al., 2001). Normally notochord flexion is accompanied by rapid development of fins and considerable increase of the muscular mass. The values of the employed condition indicators suggested that after that age (day 10) conditions improved, but at different time scales, with RNA/DNA ratios and otoliths showing delayed response.

The results described above show that otolith microstructure can be validated by biochemical indices as a tool for assessing larval growth history and nutrition but with a time lag of 1-2 days between the reaction of tryptic enzyme activity to otolith growth and RNA/DNA ratios in the Brazilian sardine.

The laboratory data results for unfed larvae given in this study can be applied as critical levels for the condition, and it becomes possible to monitor Brazilian sardine larvae in the field for a size range of 3-10 mm using biochemical indices. These data can contribute to understanding and predicting the recruitment success of a tropical fish species. It was shown that under poor feeding conditions in the laboratory, sardine larvae experienced low growth expressed by dry weight, lower tryptic enzyme activity and RNA/DNA ratios, and narrower increments in the otolith microstructure.

\section{CONCLUSIONS}

Although only young sardine larvae (0-13 days) were analysed, critical values for unfed larvae based on tryptic enzyme activity and RNA/DNA ratio are available for the Brazilian sardine and it is now possible to evaluate the significance of larval mortality due to starvation in field studies.

The effect of feeding and food withdrawal was reflected in the otolith increment widths, so daily increment readings are a suitable tool for tracing rhythmic patterns of growth related to fluctuations in environmental conditions

The notochord flexion phase is characterised by an oscillation and decrease in the values of tryptic enzyme activity, RNA/DNA and otolith increment width in the very well fed larvae, demonstrating that this is an energy-consuming event. However, their different times of reaction, with RNA/DNA ratios and otoliths showing delays in relation to trypsin responses, indicate that somatic growth and otolith growth react to food deprivation in the same time scales. 


\section{ACKNOWLEDGEMENTS}

We would like to thank Oc. Ricardo H. Ota for excellent technical support. We thank Dr E. Nonato, Dr Y. Matsuura, Dr M. Iwai, Dr Phan V. N., Dr E. Aidar $^{\dagger}$, Dr S. Lourenço, Dr N. Yamanaka, Dr M. Katsuragawa, Dr W. Ekau, E. Y. Muto, M. P. Louro and $\operatorname{Dr}$ A. C. Chatwin for their assistance. Many thanks to Dr Gunnar Joakimsson ${ }^{\dagger}$ from the Fishery Institute of Kiel University for the use of the equipment and software for otolith measurements and kindness. Dr Witt ${ }^{\dagger}$ and Dr G. Quantz from the fishfarm "Butt" provided very helpful ideas for larval fish rearing. We would like to thank the Instituto Oceanográfico (Universidade de São Paulo), the Institut für Meereskunde (Universität Kiel) and FAPESP (Fundação de Amparo à Pesquisa do Estado de São Paulo - Proc. N. 98/03492-0) for their support in this co-operation. We are grateful to the Brazilian-German Science and Technology Cooperation in Marine Sciences (MCT-CNPq/WTZ) for making this study possible.

\section{REFERENCES}

Aidar, E., S.A. Gaeta, S.M.F. Gianesella-Galvão, M.B.B. Kutner and C. Teixeira. - 1993. Ecossistema costeiro subtropical: nutrientes dissolvidos, fitoplâncton e clorofila-a e suas relações com as condições oceanográficas na região de Ubatuba, SP. Publção especial Inst. oceanogr., S Paulo, 10: 9-43.

Bergeron, J.P. - 1997. Nucleic acids in ichthyoplankton ecology: a review, with emphasis on recent advances for new perspectives. J. Fish. Biol., 51(suppl. A): 284-302.

Blaxter, J.H.S. - 1988. Pattern and variety in development. In: W.S. Hoar and D.J. Randall (eds.), Fish Physiology, pp. 1-58, Vol. 11, Part A. Academic Press, London.

Bradford, M.J. and G.H. Geen. - 1992. Growth estimates from otolith increment widths of juvenile chinook salmon (Oncorhynchus tshawytscha) reared in changing environments. J. Fish Biol., 41: 825-832.

Buckley, L.J. - 1980. Changes in ribonucleic acid, deoxyribonucleic acid and protein content during ontogenesis in winter flounder, Pseudopleuronectes americanus, and the effect of starvation. Fish. Bull, U.S., 77: 703-708.

Buckley, L.J. - 1984. RNA/DNA ratio: an index of larval fish growth in the sea. Mar. Biol., 80: 291-198.

Buckley, L.J. and R.G. Lough. - 1987. Recent growth, chemical composition and prey field of haddock (Melanogrammus aeglefinus) and cod (Gadus morhua) larvae on Georges Bank, May 1983. Can. J. Fish. aquat. Sci., 44: 14-25.

Bulow, F.J. - 1987. RNA-DNA ratios as indicators of growth in fish: A review. In: R.C. Summerfelt and G.E. Hall (eds.), Age and growth in fish, pp. 45-64. Iowa State University Press, Ames.

Campana, S.E. - 1984. Microstructural growth patterns in the otoliths of larval and juvenile starry flounder, Platichthys stellatus. Can. J. Zool., 62: 1507-1512.

Campana, S.E. and J.D. Neilson. - 1985. Microstructure of fish otoliths. Can. J. Fish. Aquat. Sci., 42: 1014-1032.

Canino, M.F., K.E. Bailey and L.S. Incze. - 1991. Temporal and geographic differences in feeding and nutritional condition of walleye pollock larvae Theragra chalcogramma, in Sheikof Strait, Gulf of Alaska. Mar. Ecol. Prog. Ser., 79: 27-35.

Cergole, M.C., S.A. Saccardo and C.L.D.B. Rossi-Wongtschowski. - (in press). Fluctuations in the spawning stock biomass and recruitment of the Brazilian sardine (Sardinella brasiliensis): 1977-1997. Rev. Bras. Oceanogr., S Paulo, 50.

Chícharo, M.A. - 1997. Starvation percentages in field caught Sardina pilchardus larvae off southern Portugal. Sci. Mar., 61(4): 507-516.

Chícharo, M.A., L. Chícharo, L. Valdés, E. López-Jamar and P. Ré. - 1998. Estimation of starvation and diel variation of the RNA/DNA ratios in field-caught Sardina pilchardus larvae off the north of Spain. Mar. Ecol. Prog. Ser., 164: 273-283.

Clemmesen, C. - 1993. Improvements in the fluorimetric determination of the RNA and DNA content of individual marine fish larvae. Mar. Ecol. Prog. Ser, 100: 177-183.

Clemmesen, C. - 1994. The effect of food availability, age and size on the RNA/DNA ratio of individually measured herring larvae: laboratory calibration. Mar. Biol., 118: 337-382.

Clemmesen, C. and T. Doan. - 1996. Does otolith structure reflect the nutritional condition of a fish larva? Comparison of otolith structure and biochemical index (RNA/DNA ratio) determined on cod larvae. Mar. Ecol. Progr. Ser., 138: 33-39.

Clemmesen, C., R. Sánchez and C. Rossi-Wongtschowski. - 1997. A regional comparison of the nutritional condition of SW Atlantic anchovy larvae, Engraulis anchoita, based on RNA/DNA ratios. Arch. Fish. Mar. Res., 45(1): 17-43.

Dias, J.F. - 1995. Avaliação da condição nutricional das larvas de sardinha-verdadeira (Sardinella brasiliensis (Steindachner, 1879)) - Clupeidae e da anchoíta (Engraulis anchoita Hubbs \& Marini, 1935) - Engraulididae, da Costa sudeste do Brasil. Ph. D. thesis, Universidade de São Paulo.

Ferron, A. and W.C. Leggett. - 1994. An appraisal of condition measures for marine fish larvae. Adv. Mar. Biol., 30: 217-303.

Fossum, P. and E. Moksness. - 1993. A study of spring and autumn spawned herring (Clupea harengus L.) larvae in the Norwegian coastal current during spring 1990. Fish. Oceanogr., 2: 73-81.

Fukuda, M., H. Nakano and K. Yamamoto. - 1986. Biochemical changes in the Pacific herring during early developmental stages. Bull. Fac. Fish. Hokkaido Univ., 37(1): 30-37.

Gauldie, R. W. and D.G.A. Nelson. - 1988. Aragonite twinning and neuroprotein secretion are the cause of daily growth rings in fish otoliths. Comp. Biochem. Physiol., 90A: 501-509.

Grønkjær, P., C. Clemmesen and M. St. John. - 1997. Nutritional condition and vertical distribution of Baltic cod larvae - migrate or die. J. Fish. Biol., 51(suppl. A): 352-369.

Hjelmeland, K., I. Huse, T. Jorgensen, G. Molvik and J. Raa. 1984. Trypsin and trypsinogen as indices of growth and survival potential of cod (Gadus morhua L.) larvae. In: E. Dahl, E. Danielssen, E. Moksness and P. Solemdal (eds), The propagation of cod, Gadus morhua, pp. 189-211, Part 1. Institute of Marine Research, Flødevigen Biological Station.

Hovenkamp, F. - 1989. Within-season variation in growth of larval plaice (Pleuronectes platessa L.). Rapp. P.-v. Réun. Cons. int. Explor. Mer.

Hovenkamp, F. - 1990. Growth differences in larval plaice (Pleuronectes platessa $\mathrm{L}$.) in the Southern Bight of the North Sea as indicated by otolith increments and RNA/DNA ratios. Mar. Ecol. Progr. Ser., 70: 105-116.

Hovenkamp, F. and J.I.J. Witte. - 1991. Growth, otolith growth and RNA/DNA ratios of larval plaice Pleuronectes platessa in the North Sea 1987 to 1989. Mar. Ecol. Prog. Ser., 58: 201-215.

Jones, C. - 1986. Determining age of larval fish with the otolith increment technique. Fish. Bull., U. -S., 84: 91-103.

Kimura, R., Y. Watanabe and H. Zenitani. - 2000. Nutritional condition of first-feeding larvae of Japanese sardine in the coastal and oceanic waters along the Kuroshio Current. ICES J. mar. Sci., 57:240-248.

Kurtz, F.W. and Y. Matsuura. - 2001. Food and feeding ecology of Brazilian sardine (Sardinella brasiliensis) larvae from the southeastern Brazilian Bight. Rev. Bras. Oceanogr., S Paulo, 49(1/2): 61-74.

Lauff, M. and R. Hofer. - 1984. Proteolytic enzymes in fish development and the importance of dietary enzymes. Aquaculture, 37: $335-346$

Maillet, G.T. and D.M. Checkley Jr. - 1989. Effects of starvation on the frequency of formation and width of growth increments in sagittae of laboratory-reared Atlantic Menhaden Brevoortia tyrannus larvae. Fish. Bull., U.S., 88: 155-165.

Martin, F.D., D.A. Wright, J.C. Means and E.F. Setzler-Hamilton. - 1985. Importance of food supply to nutritional state of larval striped bass in the Potomac river estuary. Trans. Am. Fish. Soc., 114: $137-145$. 
MacKenzie, B. Ueberschär, D. Basford, M. Heath, A. Gallego 1999: Diel Variability of feeding activity in haddock (Melanogrammus aeglifinus) larvae in the East Shetland area, North Sea. Mar. Biol., 135, 361-368

Matsuura, Y. - 1989. Synopsis on the reproductive biology and early life history of the Brazilian sardine, Sardinella brasiliensis and related environmental conditions. In: Second IOC workshop on sardine/anchovy recruitment project (SARP) in the Southwest Atlantic. UNESCO, Montevideo, Uruguay. IOC Workshop Report, 65 p.

Matsuura, Y. - 1996. A probable cause of recruitment failure of the Brazilian sardine Sardinella aurita population during the 1974/75 spawning season. S. Afr. J. mar. Sci., 17: 29-35.

Moksness, E. - 1992. Differences in otolith microstructure and body growth rate of North Sea herring (Clupea harengus L.) larvae in the period 1987-1989. ICES J. mar. Sci., 49: 223-230

Moksness, E. and P. Fossum. - 1991. Distinguishing spring- an autumn-spawned herring larvae (Clupea harengus L.) by otoliths microstructure. ICES J. mar. Sci., 48: 61-66.

Moksness, E., M. Belchier, C. Clemmesen, D. Cortés, A. Doan, A Folkvord, A. García, A.J. Geffen, H. Hoie, A. Johannessen, H. de Pontual, T. Rámirez, D. Schnack and B. Sveinsbo. -2000 Manual of tools for recruitment studies. Final Report FAIRCT96-1371, 42 pp.

Mosegaard, H., H. Svedäng and K. Taberman. - 1988. Uncoupling of somatic and otolith growth rates in Arctic Char (Salvelinus alpinus) as an effect of differences in temperature response. Can. J. Fish. aquat. Sci., 45: 1514-1524.

Mugiya, Y. and H. Oka. - 1991. Biochemical relationship between otolith and somatic growth in the rainbow trout Oncorhynchus mykiss: consequence of starvation, resumed feeding and dial variations. Fish. Bull., U.S., 89: 239-245.

Neilson, J.D. and G.H. Geen. - 1985. Effects on feeding regimes and diel temperatre cycles on otolith increment formation in juvenile chinook salmon Oncorhynchus tshawytscha. Fish. Bull., U.S., 83: 91-101.

Pannella, G. - 1971. Fish otoliths: daily growth layers and periodical patterns. Science, 173: 1124-1127.

Pannella, G. - 1980. Growth patterns in fish sagittae: In: D.C Rhodes and R.A. Lutz (eds.), Skeletal growth of aquatic organisms: biological records of environmental change, pp. 519-560. Plenum Press, New York.

Pedersen, B.H., E.M. Nilssen and K. Hjelmeland. - 1987. Variations in the content of trypsin and trypsinogen in larval herring (Clupea harengus) digesting copepod nauplii. Mar. Biol., 94: 171-181.

Pedersen, B.H., I. Ugelstad and K. Hjelmeland. - 1990. Effects of transitory, low food supply in the early life of larval herring (Clupea harengus) on mortality, growth and digestive capacity. Mar. Biol., 107: 61-66.

Raae, A.J., I. Opstad, P. Kvenseth and B.T. Walther. - 1988. RNA DNA and protein during early development in feeding and starved cod (Gadus morhua L.) larvae. Aquaculture, 73: 247-259.

Ramírez, T., D. Cortés and A. García. - 2001. Growth of North Alboran Sea sardine larvae estimated by otolith microstructure, nucleic acids and protein content. J. Fish Biol., 59: 403-415.

Rice, J.A., L.B. Crowder and F.P. Binkowski. - 1985. Evaluating otolith analysis for bloater Coregonus hoyi: do otoliths ring true? Trans. Am. Fish. Soc., 114(4): 532-539.

Rice, J.A., L.B. Crowder and M.E. Holey. - 1987. Exploration of mechanisms regulating larval survival in Lake Michigan bloater: a recruitment analysis based on characteristics of individual larvae. Trans. Am. Fish. Soc., 116: 703-718.

Robinson, S.M.C. and D.M. Ware. - 1988. Ontogenetic development of growth rates in larval Pacific herring, Clupea harengus pallasi, measured with RNA-DNA ratios in the Strait of Georgia, British Columbia. Can. J. Fish. aquat. Sci., 45: 1422-1429.

Rossi-Wongtschowski, C.L.D.B., S.A. Saccardo and M.C. Cergole. - 1996. Are fluctuations in Brazilian sardine catches related to global-scale climate changes? An. Acad. bras. Ci., 68(sup.1): 239-250.

Secor, D.H. and J.M. Dean. - 1989. Somatic growth effects on the otolith - fish size relationship in young pond-reared striped bass, Morone saxatilis. Can. J. Fish. Aquat. Sci., 46: 113-121.

Setzler-Hamilton, E.M., F. Wright, F.D. Martin, C.V. Millsaps and S. Whitlow. - 1987. Analysis of nutritional condition and its use in predicting striped bass recruitment: field studies. Am. Fish. Soc. Symp., 2: 115-128.

Suthres, I. M. - 1998. Bigger? Fatter? Or is faster growth better? Considerations on condition in larval and juvenile coral-reef fish. Australian J. Ecol., 23:265-273.

Suthers, I.M., A. Fraser and K.T. Frank. - 1992. Comparison of lipid, otolith and morphometric condition indices of pelagic juvenile cod Gadus morhua from Canadian Atlantic. Mar. Ecol. Progr. Ser., 84: 31-40.

Ueberschär, B. - 1988. Determination of nutritional condition of individual marine fish larvae by analysing their proteolytic activities with a highly sensitive fluorescence technique. Meeresforsch., 32: 144-154.

Ueberschär, B. - 1995. The use of tryptic enzyme activity measurement as a nutritional condition index: laboratory calibration data and field application. ICES mar. Sci. Symp., 201: 119-129.

Ueberschär, B. - 1999. Die Trypsinaktivität als biochemischer Indikator zur Bestimmung des Ernährungszustandes sowie der Fressaktivität von Fischlarven und seine Anwendung in Feldstudien. PhD Thesis, University of Hamburg. Weissensee Verlag, Berlin.

Ueberschär, B. and Clemmesen, C. - 1992. A comparison of the nutritional condition of herring larvae as determined by two biochemical methods - tryptic enzyme activity and RNA/DNA ratio measurements. ICES J. mar. Sci., 49: 245-249.

Valentini, H. and R.D. Cardoso. - 1991. Análise da pesca da sardinha-verdadeira (Sardinella brasiliensis) na costa sudestesul do Brasil. Atlântica, Rio Grande, 13(1): 45-54.

Yoneda, N.T. - 1987. Criação em laboratório de larvas da sardinha-verdadeira, Sardinella brasiliensis, e estudo dos incrementos diários nos otólitos. M.Sc. Dissertation, Universidade de São Paulo.

Scient. ed.: M.P. Olivar 